\title{
A study on management of hypertension in patients with type 2 diabetes mellitus in tertiary care teaching rural hospital
}

\author{
Shruti Vihang Brahmbhatt*, Bhagya M. Sattigeri
}

Department of Pharmacology, SBKS MI \& RC, Sumandeep Vidyapeeth, Piapria, Vadodara, Gujarat, India

Received: 05 September 2018 Revised: 19 September 2018 Accepted: 27 September 2018

\section{*Correspondence to:}

Dr. Shruti Vihang Brahmbhatt, Email: dr.shruti1988@ gmail.com

Copyright: (C) the author(s), publisher and licensee Medip Academy. This is an openaccess article distributed under the terms of the Creative Commons Attribution NonCommercial License, which permits unrestricted noncommercial use, distribution, and reproduction in any medium, provided the original work is properly cited.

\begin{abstract}
Background: This study was aimed to analyze the drug utilization pattern in the management of hypertension in diabetic patients.

Methods: A prospective, observational and non interventional study was conducted in 100 diabetic hypertensive patients admitted in medicine wards at Dhiraj Hospital. Patients who signed informed consent form were only included in the study. All the data were recorded from patients' case files and analyzed. Results: Of enrolled 100 patients, 69 (69\%) were male and 31 (31\%) were female and maximum number of the patients $(42 \%)$ were found in the age group of 5160 years. Out of 100 admitted patients, $75 \%$ patients were treated with single antihypertensive agent, $20 \%$ were treated with combination of two antihypertensive agents while only 5\% were administered more than two antihypertensive agents. As a single antihypertensive agent, most commonly prescribed was ACE inhibitors (32\%), Calcium Channel Blockers (23\%), Angiotensin Receptor Blockers (12\%) and $\beta 1$ blockers (8\%).

Conclusions: There was poor awareness among the patients regarding control of hypertension, regular follow up, medication adherence etc. However, two third of diabetic patients had achieved blood pressure target control and ACE inhibitor remained first choice of drug for hypertension in diabetes in this study.
\end{abstract}

Keywords: ACE inhibitors, Angiotensin receptor blockers, $\beta 1$ blockers, Calcium channel blockers, Drug utilization

\section{INTRODUCTION}

India is the diabetes capital of the world with 41 million Indians having diabetes; and by 2025 ; the expected number is 68 million. ${ }^{1}$ The long term real impact of obesity and diabetes is expressed as cardiovascular disease or hypertension which would soon take the centre stage. ${ }^{2}$

Hypertension has been important predictor of cardiovascular disease, cerebrovascular accident and death. The prevalence of cardiovascular diseases and hypertension is rapidly increasing in developing countries. ${ }^{3}$ This increase is most marked in the urban population which is likely to be related to changing lifestyles and to an increased longevity. Earlier studies in the Indian urban population reported the prevalence of hypertension as $1.2-4.0 \% .{ }^{4}$ Subsequent studies reported an increasing prevalence and current data suggest that hypertension affects nearly $25 \%$ of urban Indians. ${ }^{4-6}$ It has been reported that type 2 diabetes (T2DM) is higher in upper socio-economic strata compared with those in lower strata. ${ }^{7}$ However, such data are not available for patients with hypertension or pre-hypertension.

Hypertension is a major leading risk factor for the development and progression of macrovascular and microvascular complications in diabetic patients, which in 
turn contributes to the mortality and morbidity. ${ }^{8,9}$ Compared to the general population, diabetic individuals face a two to fourfold higher risk of cardiovascular disease (CVD). ${ }^{8,10}$ Additionally, presence of hypertension triples the already high risk of coronary artery disease (CAD) and doubles total mortality and stroke risk which may be responsible for up to $75 \%$ of all CVD events in people with diabetes. $^{10}$

The strict glycemic and blood pressure control in hypertensive diabetic patients decrease both macrovascular and microvascular complications. A single randomized clinical trial and prospective observational data from three other clinical trials support the improved cardiovascular disease and microvascular outcomes with a target systolic blood pressure $<130 \mathrm{mmHg} .{ }^{11-13}$ Based on these data, most of the international guidelines now recommend a target blood pressure $<130 / 80 \mathrm{mmHg}$ for people with diabetes. ${ }^{11,14,15}$ So, intensive blood pressure control is an essential component of a multifactorial strategy to reduce cardiovascular and microvascular complications in diabetes.

Hypertension, particularly systolic hypertension, may be intrinsically more difficult to control in the diabetic individuals. In community settings, patients with diabetes are less likely to have their blood pressure controlled, despite receiving more antihypertensive medications. ${ }^{16} \mathrm{~A}$ clinical trial has observed that diabetic patients require $50 \%$ more antihypertensive medications to control blood pressure in comparison of non diabetic individuals. ${ }^{17}$ Patient factors contribute to poor blood pressure control through non adherence to medications and follow up visits due to health care cost and inadequate knowledge about hypertension and CVD risk. ${ }^{11}$

\section{METHODS}

A prospective, observational and non-interventional study was conducted in total 100 hypertensive diabetic patients admitted in the medicine wards at Dhiraj hospital, a tertiary care teaching rural hospital affiliated to SBKS Medical Institute and Research Centre, run under Sumandeep Vidyapeeth over a period of 15 months starting from November 2012 till May 2014. This study was conducted only after obtaining an approval from the Institutional Ethics Committee.

\section{Inclusion criteria}

- $\quad$ Patients of either sex and of age 18 and above were included in this study.

- Patients who were diagnosed as hypertensive with diabetes mellitus were included.

- $\quad$ Patients who were willing to sign informed consent form were only included.

\section{Exclusion criteria}

- Patients who were not willing to participate in study.
- Hypertensive patients who were non-diabetics.

- Diabetic patients who were normotensive.

- Patients with diabetes insipidus.

All the patients participating in the study were explained clearly about the purpose and nature of the study in the language they could understand. They were included in the study only after obtaining a written Informed Consent Form. Patient's information about age, sex, occupation, medical history, personal history, family history and past history were recorded in Case Record Form. Details of the antihypertensive drugs such as the dose, duration, frequency of administration and dosage forms used were also recorded. All the indoor patients included in this study were followed up daily till they were discharged from the hospital and all necessary information were recorded in a Case Record Form. After recording the information in Case Record Form, the data were analysed percentage wise and no statistical analysis was done.

\section{RESULTS}

Out of 100 patients suffering from diabetes with hypertension in the study, hypertension was observed to be more common in male patients $(69 \%)$ than in female patients $(31 \%)$. The highest number of patients $34(34 \%)$ belonged to the age group of 51 to 60 years (Group IV) followed by $34(34 \%)$ group V (>6o years), 21 (21\%) in group III (41-50 years) and $3(3 \%)$ in group II (31-40 years) (Table 1).

Table 1: Group of patients according to their age.

\begin{tabular}{|llll|}
\hline $\begin{array}{l}\text { Group (age in } \\
\text { years) }\end{array}$ & $\begin{array}{l}\text { Male } \\
(\%)\end{array}$ & $\begin{array}{l}\text { Female } \\
(\%)\end{array}$ & $\begin{array}{l}\text { Total (\%) } \\
(\mathbf{n = 1 0 0 )}\end{array}$ \\
\hline Group I (18-30) & 0 & 0 & 0 \\
\hline Group II (31-40) & 1 & 2 & 3 \\
\hline Group III (41-50) & 15 & 6 & 21 \\
\hline Group IV (51-60) & 25 & 17 & 42 \\
\hline Group V $(>60)$ & 28 & 6 & 34 \\
\hline
\end{tabular}

Of the enrolled patients, 91 (91\%) already had hypertension with diabetes, while $9(9 \%)$ were detected having hypertension with diabetes at the time of admission. Considering the addiction history, out of 100 patients, $15(15 \%)$ were addicting to smoking and 24 (24\%) were addict to tobacco chewing. The literacy status in the participants varied from Illiteracy to graduation. Among them, 38 (38\%) were illiterate, 48 (48\%) were literate up to $12^{\text {th }}$ standard, and $14(14 \%)$ were graduates.

It was observed that higher number of patients were admitted for respiratory diseases that was $17(17 \%)$ followed by, 15 (15\%) for cardiovascular conditions, 14 (14\%) for renal conditions, $14(14 \%)$ for genitourinary problems, $12(12 \%)$ patients were admitted for gastrointestinal diseases while only $4(4 \%)$ patients were admitted for uncontrolled diabetes and hypertension. Apart from this, $24(24 \%)$ patients were admitted for 
miscellaneous conditions which included diabetic foot, diabetic retinopathy and septicaemia.

All the patients' case files were analyzed for the management of hypertension. Of 100 patients, $75(75 \%)$ patients were prescribed single antihypertensive agent, 20 $(20 \%)$ were treated with two antihypertensive agents and $5(5 \%)$ were treated with more than two antihypertensive agents. In patients treated with single antihypertensive agent, ACE Inhibitors were most commonly prescribed (32\%) followed by Calcium Channel Blockers (23\%), Angiotensin Receptor Blockers (12\%) and $\beta 1$ blockers (8\%) (Figure 1). In patients who received two antihypertensive agents, the prescribed combinations were Losartan + Hydrochlorthiazide (13\%), Amlodipine + Atenolol (5\%), Telmisartan + Hydrochlorthiazide $(2 \%)$ as shown in Table 2.

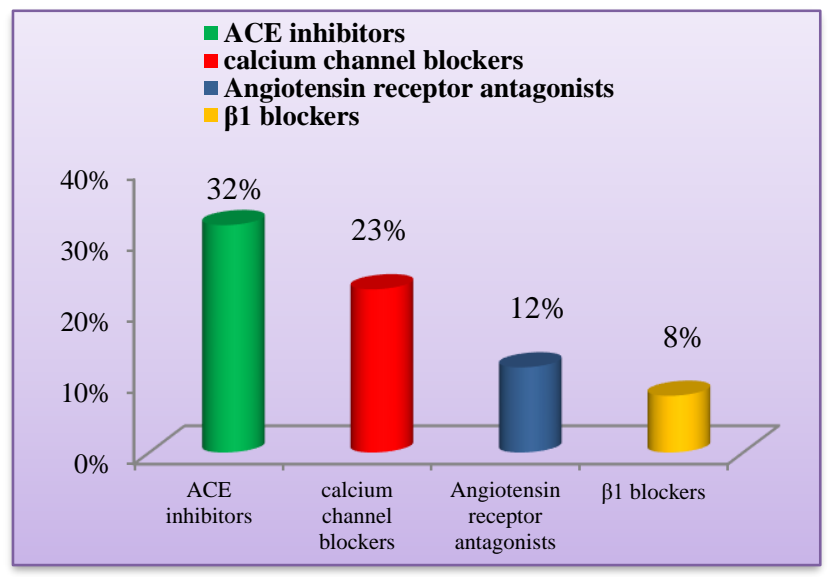

Figure 1: Percentage of commonly prescribed antihypertensive agents in patients treated with single antihypertensive agent.

Table 2: Percentage of patients and commonly used single antihypertensive agents.

\begin{tabular}{|lll|}
\hline \multirow{2}{*}{$\begin{array}{l}\text { Group of } \\
\text { antihypertensiv } \\
\text { e agents }\end{array}$} & $\begin{array}{l}\text { Antihypert } \\
\text { ensive } \\
\text { agents used }\end{array}$ & $\begin{array}{l}\text { Percentage of } \\
\text { patients as a } \\
\text { single } \\
\text { antihypertensive } \\
\text { agent) }\end{array}$ \\
\hline \multirow{2}{*}{$\begin{array}{l}\text { Calcium channel } \\
\text { blockers }\end{array}$} & Amlodipine & $14 \%$ \\
\cline { 2 - 3 } Angiotensin & Nifedipine & $5 \%$ \\
\hline receptor & Clinidipine & $4 \%$ \\
\hline antagonists & Losartan & $6 \%$ \\
\hline \multirow{3}{*}{$\beta 1$ blockers } & Telmisartan & $4 \%$ \\
\cline { 2 - 3 } & Alsartan & $1 \%$ \\
\hline \multirow{2}{*}{ ACE inhibitors } & Olmesartsn & $1 \%$ \\
\hline & Metoprolol & $4 \%$ \\
\hline & Atenolol & $2 \%$ \\
\hline & Nebivolol & $2 \%$ \\
\hline & Ramipril & $12 \%$ \\
\hline
\end{tabular}

The patients in whom target blood pressure was not achieved with single antihypertensive agent or with combination of two antihypertensive agents were additionally treated with various other antihypertensive agents like $\alpha+\beta$ blockers and centrally acting antihypertensive agents (Table 3 ).

Table 3: Percentage of patients received other antihypertensive agents in addition of single or combination of two antihypertensive agents.

\begin{tabular}{|lll|}
\hline Group of & \multicolumn{1}{|c|}{$\begin{array}{l}\text { Percentage of } \\
\text { patients who } \\
\text { antihypertensive } \\
\text { agents }\end{array}$} & $\begin{array}{l}\text { Antihyperten } \\
\text { sive agents } \\
\text { untihypertensive } \\
\text { agents in } \\
\text { addition of other } \\
\text { antihypertensive } \\
\text { agents }\end{array}$ \\
\hline$\alpha+\beta$ blockers & Carvedilol & $5 \%$ \\
\hline$\alpha$-blockers & Prazosin & $3 \%$ \\
\hline $\begin{array}{l}\text { centrally acting } \\
\text { antihypertensive } \\
\text { agents }\end{array}$ & Clonidine & $4 \%$ \\
\cline { 2 - 3 } $\begin{array}{l}\text { Arteriolar } \\
\text { vasodilators }\end{array}$ & Methyldopa & $1 \%$ \\
\hline
\end{tabular}

In patients who were treated with single antihypertensive agent, Enalapril (15\%) was single most commonly prescribed agent among ACE inhibitors, followed by Amlodipine (14\%) in CCBs, Losartan (6\%) in ARBs and Metoprolol (4\%) in $\beta 1$ blockers (Table 4).

Table 4: Percentage of patients received combination of two antihypertensive agents.

\begin{tabular}{|ll|}
\hline $\begin{array}{l}\text { Combination of two } \\
\text { antihypertensive agents }\end{array}$ & $\begin{array}{l}\text { Number of } \\
\text { patients }(\boldsymbol{\%}) \\
(\mathbf{n}=\mathbf{1 0 0})\end{array}$ \\
\hline Amlodipine + Atenolol & 5 \\
\hline Losartan + Hydrochlorthiazide & 13 \\
\hline Telmisartan + Hydrochlorthiazide & 2 \\
\hline
\end{tabular}

\section{DISCUSSION}

The prevalence of hypertension in diabetic patients is higher in comparison of non-diabetic individuals. ${ }^{18}$ Existence of Hypertension along with Diabetes has been affecting the population at both the developing and developed countries. Such coexistence has been contributing to the premature complications and thus increasing morbidity and mortality in future, particularly, the risk of mortality increases in patients who has proteinuria. Hence, timely and prompt diagnosis, life style modifications along with regular treatment would help to reduce the risk potentials and mortality risk. ${ }^{18-20}$ The present study investigated the management of hypertension in patients with concurrent diabetes mellitus living in a rural setting. 
It was found that hypertension was predominant in men (69\%) than in women $(31 \%)$, which is similar to the observations made by Rachana et al, and Supratim Datta. ${ }^{21,22}$ while in contrast to this, female preponderance in hypertension was observed by a study conducted by Shyam et al, and Mirxa Atif Beg et al. ${ }^{23,24}$

The prevalence of hypertension in diabetic patients was found highest (42\%) age group of 51-60 years which is relatively comparable with a study conducted by Supratim Datta. ${ }^{22}$ Education level significantly affects the control of hypertension in diabetics and patient who are aware of complications have better blood pressure control. In a study conducted by White et al showed that control of hypertension was higher in those who were aware of their hypertension which was in concurrence to our observation which showed higher prevalence of hypertension in literate diabetic patients $(62 \%)$ compared to in illiterate $(38 \%) .^{25}$

Smoking is considered a powerful risk factor for hypertension and diabetes management according to guidelines of the European Society of Hypertension. ${ }^{26}$ In the present study, one fourth of the patients $(24 \%)$ were habituated to tobacco chewing.

Most of the hypertensive diabetic patients are hospitalized due to poor blood pressure and poor glycemic control with microvascular or macrovascular complications. In this study set up, higher numbers of patients were admitted for respiratory disease (17\%), renal and genitourinary complications (14\%) and cardiovascular complications (15\%), while in miscellaneous conditions diabetic foot, diabetic retinopathy and septicemia was found in higher proportion. Similarly, a study done by Amanda et al observed high occurrence of myocardial infarction in diabetic hypertensive patients in comparison of micro vascular complications. ${ }^{27}$

For the management of hypertension in diabetes, most patients require more than one antihypertensive agent. ${ }^{28}$ However in this study, control of Blood pressure was achieved in more than half $(75 \%)$ of total patients with single antihypertensive agent. The most commonly prescribed class of antihypertensive as monotherapy were ACE Inhibitors (32\%), Calcium Channel Blockers (23\%), Angiotensin Receptor Blockers (12\%) and $\beta 1$ blockers $(8 \%)$.

In the general nonblack population, including those with diabetes, the initial antihypertensive treatment should include either a Thiazide, Calcium channel blocker (CCB), Angiotensin-converting enzyme inhibitor (ACEI), or Angiotensin receptor blocker (ARB). In the general black population, including those with diabetes, initial antihypertensive treatment should include a thiazide-type diuretic or CCB. In adults with CKD, initial (or add-on) antihypertensive treatment should include an ACEI or ARB to improve the kidney outcomes. ${ }^{29}$ similarly, in this study the ACE inhibitor and calcium channel blockers were most commonly prescribed antihypertensive agents as monotherapy as well as in combination also in diabetic hypertensive patients.

Beta-blockers promote weight gain while both Thiazides and Beta-blockers are associated with an increased incidence of diabetes, compared to CCB and ACEI ${ }^{30}$ In this study Cardio selective $\beta 1$ blockers were administered as monotherapy and in combination with calcium channel blockers. Irrespective of diabetes, Beta blockers are clearly indicated in patients with significant coronary artery disease, heart failure and some arrhythmias, yet less efficient in the prevention of stroke events. ${ }^{31}$

\section{CONCLUSION}

There was poor awareness among the patients regarding control of hypertension, regular follow up, medication adherence etc. However, in this study it was found that literacy is not associated with hypertension and diabetes as high prevalence of hypertension was found in literate patients. Almost two third of diabetic patients had achieved blood pressure target control and ACE inhibitor remained first choice of drug for hypertension in diabetes in this study. Angiotensin Receptor Blockers (ARBs) and calcium channel blockers were also prescribed to many patients and were successful to achieve target blood pressure.

\section{Funding: No funding sources}

Conflict of interest: None declared

Ethical approval: The study was approved by the Institutional Ethics Committee

\section{REFERENCES}

1. Joshi SR. Management of obese Indian patient. Indian J Obesity. 2005;i(1):11-20.

2. Mohan V, Deepa M, Farooq S, Datta M, Deepa R. Prevalence, awareness and control of hypertension in chennai-the chennai urban rural epidemiology study (cures-52). J Assoc Physicians Ind. 2007;55:326-32.

3. Yadav S, Boddula R, Genitta G, Bhatia V, Bansal B, Kongara S, et al. Prevalence \& risk factors of prehypertension \& hypertension in an affluent north Indian population. Ind J Med Reseae. 2008 Dec $1 ; 128(6)$.

4. Gupta R. Trends in hypertension epidemiology in india. J Hum Hypertens. 2004;18:73-8.

5. Gupta R, Gupta S, Gupta VP, Prakash H. Prevalence and determinants of hypertension in the urban population of Jaipur in western India. J Hypertens. 1995; 13:1193-200.

6. Anand MP. Prevalence of hypertension amongst Mumbai executives. J Assoc Physicians India 2000;48:1200-1.

7. Ramachandran A, Snehalatha C, Kapur A, Vijay V, Mohan V, Das AK, et al. High prevalence of diabetes and impaired glucose tolerance in India: National 
urban diabetes survey. Diabetologia. 2001;44:1094101.

8. Beckman JA, Crenger MA, Libby P. Diabetes and atherosclerosis: epidemiology, pathophysiology, and management. JAMA. 2002;287:2570-81.

9. Libby P, Nathan DM, Abraham K, Brunzell JD, Fradkin JE, Haffner SM, et al. Report of the national heart, lung, and blood institute: National institute of diabetes and digestive and kidney diseases working group on cardiovascular complications of type 1 diabetes mellitus. Circulation. 2005;111:3489-93.

10. Sowers JR, Epstein M, Frolich ED. Diabetes, hypertension, and cardiovascular disease: an update. Hypertension. 2001;37:1053-9.

11. Stults B, Jones RE. Management of hypertension in diabetes. Diabetes Spectrum. 2006;19(1):25-31.

12. Bakris GL, Gaxiola E, Messerli FH, Mancia G, Erdine $\mathrm{S}$, Cooper-Dehoff $\mathrm{R}$, et al. Clinical outcomes in the diabetic cohort of the international Verapamil SR Trandolapril study. Hypertension. 2004;44:643-8.

13. Berl T, Hunsicker LG, Lewis JB, Pfeffer MA, Porush JG, Rouleau JL, et al. Impact of achieved blood pressure on cardiovascular outcomes in the Irbesartan diabetic nephropathy trial. J Am Soc Nephrol. 2005;16:2170-9.

14. Williams B, Poulter NR, Brown MJ, Davis M, Mcinnes GT, Potter JF, et al. Guidelines for the management of hypertension: report of the fourth working party of the British hypertension society, 2004. J Human Hypertens. 2004;18:139-85.

15. European societies of hypertension and cardiology. Guidelines for the management of arterial hypertension, 2003. J Hypertens. 2003;21:1011-52.

16. Majernick TG, Zacker C, Madden NA, Belletti DA, Arcona S. Correlates of hypertension control in a primary care setting. Am J Hypertens. 2004;17:91520.

17. Brown MJ, Castaigne A, de Leeuw PW, Mancia G, Palmer CR, Rosenthal T, et al. Influence of diabetes and type of hypertension on response to antihypertensive treatment. Hypertension. 2000;35:1038-42.

18. Shah A, Afzal M. Prevalence of diabetes and hypertension and association with various risk factors among different muslim populations of Manipur, India. Journal of Diabetes and Metabolic Disorders. 2013;12:52.

19. Brahmbhatt SV, Sattigeri BM, Nil AK, Parikh DP, Shah HS, A prospective study on drug utilization pattern and rationality in treatment of type II diabetes mellitus: a population based analysis. Int J Res Med Sci. 2014;2:983-7.

20. Konzem SL. Controlling Hypertension in Patients with Diabetes. American Family Physician. 2002;66(7).
21. Rachana PR, Anuradha HV. Anti hypertensive prescribing patterns and cost analysis for primary hypertension: a retrospective study. Journal of clinical and diagnostic research: JCDR. 2014 Sep;8(9):HC19.

22. Datta S. Utilization Study of Antihypertensives in a South Indian Tertiary Care Teaching Hospital and Adherence to Standard Treatment Guidelines. J Basic Clin Pharma. 2017;8:33-7.

23. Beg MA, Dutta S, Varma A, Kant R, Bawa S, Anjoom $\mathrm{M}$, et al. A study on drug prescribing pattern in hypertensive patients in a tertiary care teaching hospital at Dehradun, Uttarakhand. Int J Med Sci Public Health. 2014;3:922-6.

24. Ganguly SS, Shafaee MA, Bhargava K, Duttagupta KK. Prevalence of prehypertension and associated cardiovascular risk profiles among Omani adults. BMC Public Health. 2008;8:108.

25. White F, Wang L, Jelinek HF. Management of hypertension in patients with diabetes mellitus. Exp Clin Cardiol. 2010;15(1):5-8.

26. Robert H, Fagard. Smoking amplifies cardiovascular risk in patients with hypertension and diabetes. Diabetes Care. 2009;32(suppl 2):s429-s431.

27. Adler AI, Stratton IM, Neil HA, Yudkin JS, Matthews DR, Cull CA, et al. Association of systolic blood pressure with macrovascular and microvascular complications of type 2 diabetes (UKPDS 36): Prospective observational study. BMJ. 2000;321:4129.

28. Vijan S, Hayward RA. Treatment of hypertension in type 2 diabetes mellitus: Blood Pressure goals, choice of agents, and setting priorities in diabetes care. Annals of Internal Medicine. 2003;138(7):593-603.

29. James PA, Oparil S, Carter BL, Cushman WC, Dennison-Himmelfarb C, Handler J, et al. 2014 Evidence-Based Guideline for the management of high blood pressure in adults report from the panel members appointed to the Eighth Joint National Committee (JNC 8). JAMA. 2014 Feb 5;311(5):50720.

30. Messerli FH, Grossman E, Leonetti G. Antihypertensive therapy and new onset diabetes. J Hypertens. 2004;22:1845-7.

31. Standl E, Erbach, Schnell O. What should be the antihypertensive drug of choice in diabetic patients and should we avoid drugs that increase glucose levels? Pro and Cons. Diabetes Metab Res Rev. 2012;28(Suppl 2):60-6.

Cite this article as: Brahmbhatt SV, Sattigeri BM. A study on management of hypertension in patients with type 2 diabetes mellitus in tertiary care teaching rural hospital. Int J Basic Clin Pharmacol 2018;7:2196-200. 